\title{
Cactus diversity in the Sierra del Rosario, Durango, Mexico
}

\author{
Diversidad cactológica de la Sierra del Rosario, Durango, México \\ Josué Raymundo Estrada-Arellano ${ }^{1}$, Andres Eduardo Estrada-Castillón ${ }^{2}$, María Magdalena Salinas- \\ Rodríguez $^{3 *}$, Jaime Sánchez-Salas ${ }^{1}$, Edgar Omar Rueda-Puente ${ }^{1}$, Cándido Márquez-Hernández ${ }^{1 \dagger}$ \\ ${ }^{1}$ Facultad de Ciencias Biológicas, Universidad Juárez del Estado de Durango, Av. Universidad s/n, Fracc. Filadelfia, CP. 35010, \\ Gómez Palacio, Durango, México. \\ ${ }^{2}$ Facultad de Ciencias Forestales, Universidad Autónoma de Nuevo León, Carretera Nacional 85, Km. 145, Linares, Nuevo \\ León, México. \\ ${ }^{3}$ Herbario Isidro Palacios, Instituto de Investigaciones de Zonas Desérticas, Universidad Autónoma de San Luis Potosí, Altair \\ 200, Col. del Llano, CP. 78377, San Luis Potosí, México. \\ *Corresponding author: manesalinas@outlook.com
}

Scientific note received: 17 de febrero de 2016 accepted: 15 de mayo de 2017

\begin{abstract}
The Sierra del Rosario is a calcareous mountainous area located in the northeast region of the state of Durango, where xerophilous vegetation and chaparral predominate. The aim of this study was to determine cactus diversity and distribution in the region. A list of cacti was obtained from 15, $3 \mathrm{~km}$ transects covering the vegetation of microphyllous desert shrubland, rosetophyllous desert shrubland and chaparral. A total of 33 species and 13 genera were recorded, with the most representative genera being Coryphantha, Echinocereus and Mammillaria. There are six species in some category of risk according to NOM-059-SEMARNAT-2010, distributed in the genera Coryphantha, Glandulicactus and Peniocereus. No species was found at risk in the IUCN, while Coryphantha sneedii is in the CITES. Species richness estimators indicate that diversity ranges from 34 to 47 taxa. The greatest diversity is between 1207 and 1400 masl in the rosetophyllous desert shrubland.
\end{abstract}

Key words: Cacti, conservation, diversity, risk, transects

RESUMEN. La Sierra del Rosario es un área montañosa calcárea ubicada al noreste del estado de Durango. El objetivo fue conocer la diversidad cactológica y su distribución en la Sierra del Rosario. Se presenta un listado de cactáceas proveniente de 15 transectos de $3 \mathrm{~km}$, en la vegetación de matorral desértico micrófilo, matorral desértico rosetófilo y chaparral. Se registraron 33 especies y 13 géneros, los géneros más representativos son Coryphantha, Echinocereus y Mammillaria. Se encontraron seis especies en alguna categoría de riesgo en la NOM-059-SEMARNAT2010, de los géneros Coryphantha, Glandulicactus y Peniocereus. No se encontró ninguna especie en riesgo en la UICN, mientras que en la CITES se encuentra Coryphantha sneedii. Los estimadores de riqueza de especies indican que la diversidad oscila entre 34 y 47 taxa. La mayor diversidad se encuentra entre 1207 y 1400 msnm en el matorral desértico rosetófilo.

Palabras clave: Cactáceas, conservación, diversidad, riesgo, transectos

\section{INTRODUCTION}

The family Cactaceae is one of the most representative groups of angiosperms in the biological diversity of Mexico. It constitutes a diverse group of plants with great morphological and taxonomic variety (Hernández et al. 2007). Cacti, which are the most characteristic plants of
Mexico's arid landscape (Mabberley 1997), are distributed in the north and center of the country. There are around 1400 species of cacti in the world (Mabberley 1997). In this respect, Villaseñor (2016) indicates that the family Cactaceae is the seventh most diverse family with 62 genera and 677 species, of which 518 are endemic to Mexico, while Ortega-Baes and Godínez-Alvarez (2005) mention 
that Mexico is the country with the most endemic cactus species, with around $49 \%$. At present, the family faces ecological, biogeographical and anthropogenic threats that put them at risk of extinction, such as restricted geographical distribution, long life cycles, low growth rates, land-use change and illegal collection of their populations for sale in the black market (Godínez-Álvarez et al. 2003).

The State of Durango stands out for having a varied complexity of physiography and climates, which translates into plant species richness (González et al. 1991). The Sierra del Rosario is a mountainous massif of sedimentary origin covering 70000 ha located in the northeast section of the State of Durango, within the bioregion of the Great Chihuahuan Desert, which forms the westernmost portion of the physiographic subprovince of the Sierras Transversales of the Sierra Madre Oriental (INEGI 2001). For all of the above, the aim of this research was to determine cactus diversity and distribution in the Sierra del Rosario.

\section{MATERIALS AND METHODS}

\section{Study area}

The Sierra del Rosario is located in the northeast region of the State of Durango, at coordinates $25^{\circ} 45^{\prime \prime} 54.94^{\prime}$ and $25^{\circ} 1^{\prime \prime} \quad 41.21^{\prime}$ $\mathrm{NL}, 104^{\circ} 03^{\prime \prime} 18.18^{\prime}$ and $103^{\circ} 43^{\prime \prime} 42.15^{\prime} \mathrm{WL}$, with an approximately 70000 ha area (Figure 1). Its orography is composed of mountain ranges, plateaus, ravines and intermontane valleys with minimum and maximum elevations of 1206 and 2 833 masl, respectively. It is composed of limestone rocks and lithosol soils, with average annual rainfall of $290 \mathrm{~mm}$ and an average temperature of $17.5^{\circ} \mathrm{C}$. Its main type of vegetation (59.5\%) consists of rosetophyllous desert shrubland, followed by chaparral (35\%), microphyllous desert shrubland (4.2\%) and grasslands (1.3\%).

\section{Field work}

Fifteen $3 \mathrm{~km}$ transects were made based on accessibility, in an attempt to cover all types of vegetation present in the Sierra del Rosario, passing through canyons, ravines, streams and hills during the spring, summer and autumn of 2013 and 2014. In each transect, species, vegetation type according to the classification of INEGI (2011), elevation of the site and photographic material of the cactus present were recorded (Lebgue et al. 2011). The individuals found were photographed to identify them with the aid of Guzmán et al. (2007) and Lebgue et al. (2011). The status of species in a risk category was obtained from NOM-059-SEMARNAT-2010, the International Union for the Conservation of Nature (IUCN) and the Convention on International Trade in Endangered Species of Wild Fauna and Flora (CITES).

\section{Richness estimators}

Species richness and estimation of sampling efficiency were analyzed using the non-parametric Ace, Chao 1, Chao 2, Jackknife 1, Jackknife 2 and Bootstrap estimators, using EstimateS software version 9.1 (Colwell 2013). To evaluate the estimators, the species accumulation curves were visually analyzed; it was thought that the most appropriate richness estimators are those whose accumulation curves had a high initial growth rate and defined asymptote (Gotelli and Colwell 2001, López and Williams 2006).

\section{Abundance models}

Four chi-square goodness of fit tests of abundance were performed with the Past 3 program, per species obtained from the sampled sites with respect to the log-normal distribution, logarithmic series, broken stick model and geometric series (Moreno and Halffter 2001, Magurran 2004), in order to determine a possible model that describes the structure and state of the community to which the abundance data of the species are fitted.

\section{Similarity index}

A presence-absence matrix of the species identified in the 15 sampling transects was constructed, with which a cluster analysis was performed using the Sorensen similarity index. To determine the similarity among sampling sites, the 


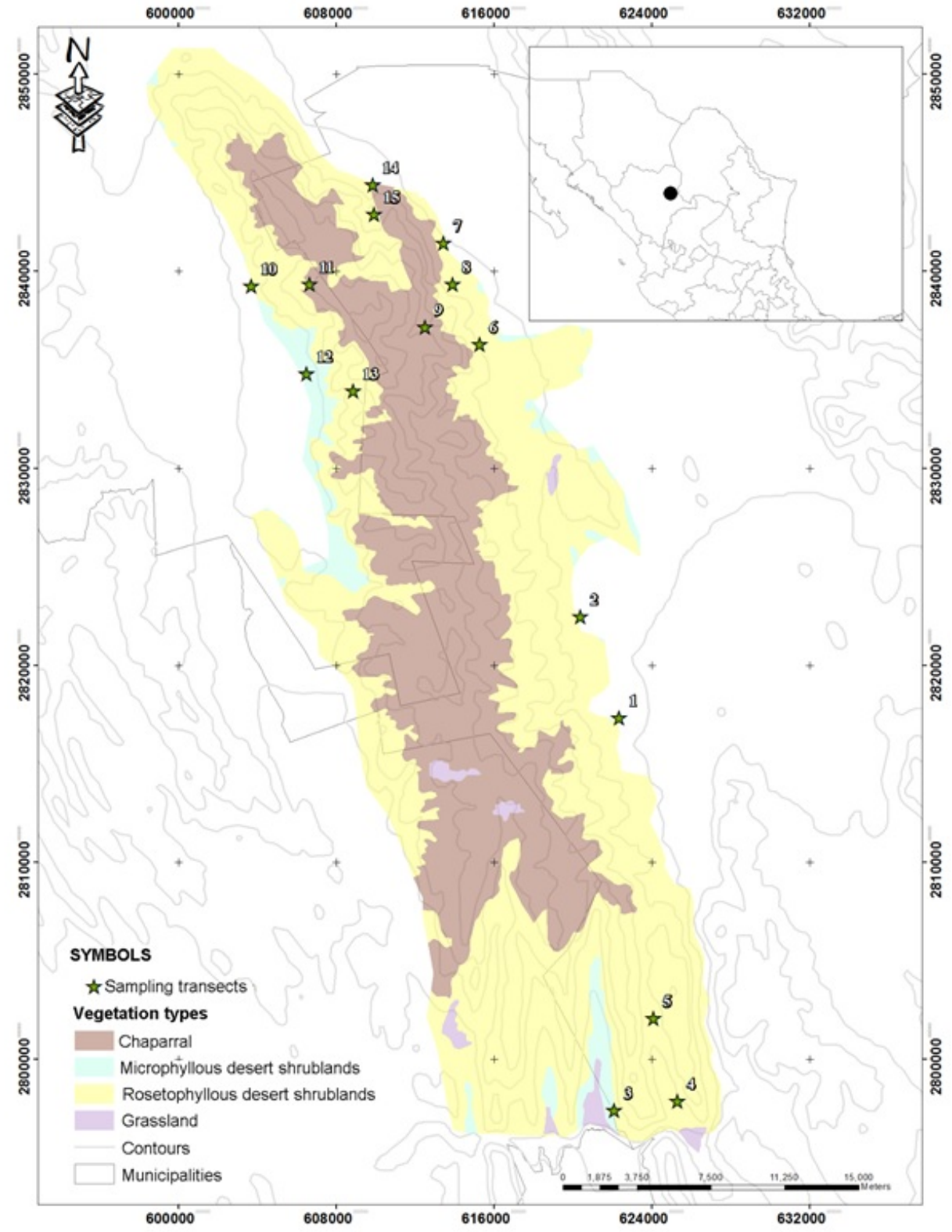

Figure 1. Vegetation types of the Sierra del Rosario and location of the sampling transects.

dendrogram was constructed using the UPGMA method (McCune 1995) with MVSP software 3.2.

\section{RESULTS AND DISCUSSION}

We identified a total of 33 species and 13 genera, of which 30 species were in a conservation category, six in NOM-059-SEMARNAT-2010, 23 in the IUCN and one in Appendix I of CITES (Table 1). The genera Coryphantha, Echinocereus and Mammillaria were the most representative (Figure 2). In this regard, Hernández et al. (2004) mention 
Table 1. List of cactus flora of the Sierra del Rosario

\begin{tabular}{|c|c|c|c|}
\hline Species & NOM-059 & IUCN & CITES \\
\hline Corynopuntia schottii (Engelm.) F.M.Knuth & & MC & \\
\hline Coryphantha cornifera (DC.) Lem. & & MC & \\
\hline Coryphantha delaetiana A. Berger. & & & \\
\hline Coryphantha durangensis (Runge ex K. Schum.) Britton \& Rose. & $\operatorname{Pr}$ & MC & \\
\hline Coryphantha echinus (Engelm.) Orcutt. & & & \\
\hline Coryphantha poselgeriana (A. Dietr.) Britton \& Rose. & $\mathrm{T}$ & MC & \\
\hline Coryphantha pseudoechinus Boed. & $\operatorname{Pr}$ & MC & \\
\hline Coryphantha ramillosa Cutak. & $\mathrm{T}$ & MC & \\
\hline Coryphantha sneedii (Britton \& Rose) A Berger & & & I \\
\hline Cylindropuntia imbricata (Haw.) F.M. Knuth. & & MC & \\
\hline Cylindropuntia kleiniae (DC.) & & MC & \\
\hline Cylindropuntia leptocaulis (DC.) F.M. Knuth. & & MC & \\
\hline Echinocactus horizonthalonius Lem. & & MC & \\
\hline Echinocereus coccineus Engelm. & & MC & \\
\hline Echinocereus dasyacanthus Engelm. & & MC & \\
\hline Echinocereus enneacanthus Engelm. & & MC & \\
\hline Echinocereus pectinatus (Scheidw.) Engelm. & & MC & \\
\hline Echinocereus stramineus ssp. Occidentalis (Engelm.) F.Seitz & & MC & \\
\hline Echinomastus durangensis (Runge) Britton \& Rose & & & \\
\hline Escobaria tuberculosa (Engelm.) Britton \& Rose & & MC & \\
\hline Escobaria zilziana (Boed.) Backeb. & & & \\
\hline Ferocactus hamatacanthus (Muehlenpf.) Britton \& Rose & & MC & \\
\hline $\begin{array}{l}\text { Glandulicactus uncinatus spp. wrightii (Engelm.) U.Guzmán } \\
\text { Mammillaria chionocephala J.A. Purpus }\end{array}$ & $\mathrm{T}$ & MC & \\
\hline Mammillaria heyderi spp. meiacantha (Engelm.) D.R. Hunt & & MC & \\
\hline Mammillaria lasiacantha Engelm. & & MC & \\
\hline Mammillaria pottsii Scheer ex Salm-Dyck. & & MC & \\
\hline Mammillaria wagneriana Boed. & & & \\
\hline Opuntia engelmannii Salm-Dyck ex Engelm. & & MC & \\
\hline Opuntia phaeacantha Engelm. & & MC & \\
\hline Opuntia rufida Engelm. & & $\mathrm{MC}$ & \\
\hline Peniocereus greggii (Engelm.) Britton \& Rose & $\operatorname{Pr}$ & $\mathrm{MC}$ & \\
\hline Thelocactus bicolor (Galeotti) Britton \& Rose & & & \\
\hline
\end{tabular}

that there are 324 species in the Chihuahuan Desert, while Sánchez et al. (2014) report 59 species and 14 in the threatened and special protection category in the Sierra del Sarnoso by NOM-059-SEMARNAT 2010, which has vegetation similar to the Sierra del Rosario. It is known that Mexico's mountains are often concentration areas for endemic species, due to the heterogeneity of the relief for the colonization of new species with wide elevational ranges in short distances, complex orography and diversity of vegetation types (Sosa y De-Nova 2012, Rzedowski 2015, Gómez-Díaz et al. 2017).

The estimators indicated the presence of between 34 and 47 species. The estimator with the closest result to the number of observed species was Chao 2 with 34 species, followed by Ace, Bootstrap and Jacknife with 35 species each, whereas Jack- nife 2 indicated 38 species and Chao 147 species (Figure 3). In this regard, Villareal et al. (2004) mention that non-parametric estimators are useful for estimating species richness; therefore, the results indicate that there was a good sampling, with an efficiency of $97 \%$, so these estimators can be used to make sampling more efficient, especially in areas with climatic conditions such as those of xerophilous shrubland.

The diversity and abundance models were not fitted to the geometric series and broken stick models ( $p<0.05$ ), so it can be deduced that the measured transects come from an ecosystem rich in cactus species and do not present a state of severe disturbance, while the logarithmic and lognormal distribution models were adequately fitted to the diversity-abundance distributions, with sig- 
Estrada-Arellano et al.

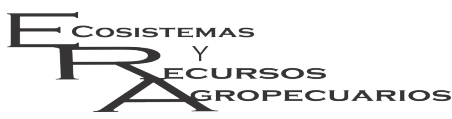

Diversity of Cactaceae in Sierra del Rosario, Mexico

Ecosist. Recur. Agropec.

5(13):133-141,2018
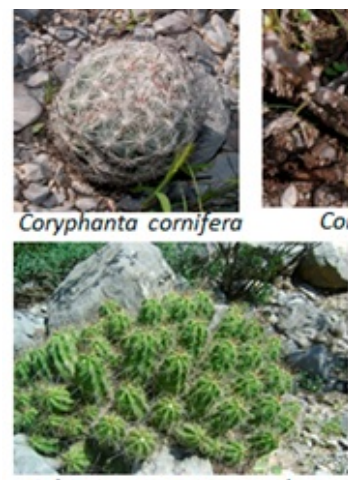

Echinocereus enneacanthus

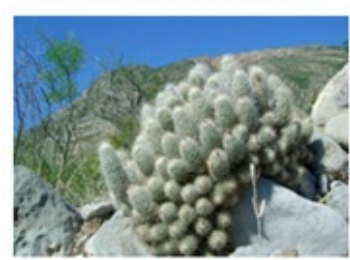

Coryphantha sneedii

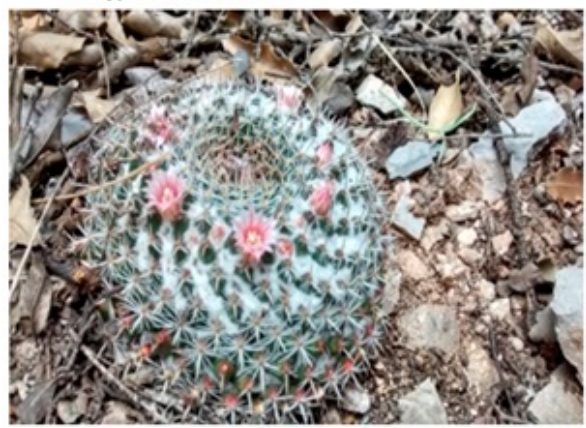

Mammillaria heyderi

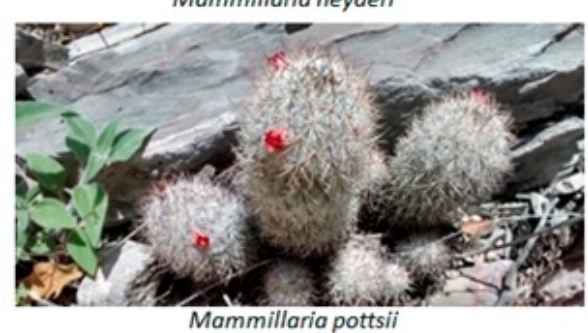

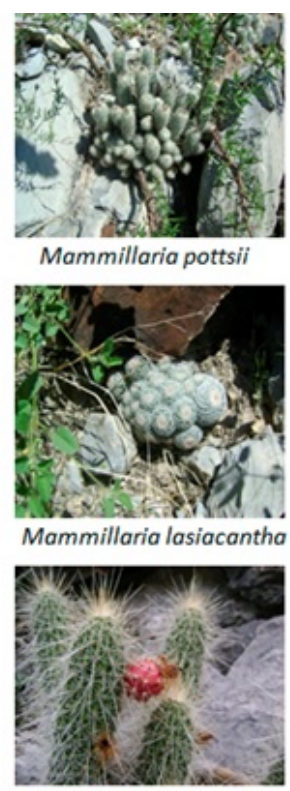

Echinocereus coccineus
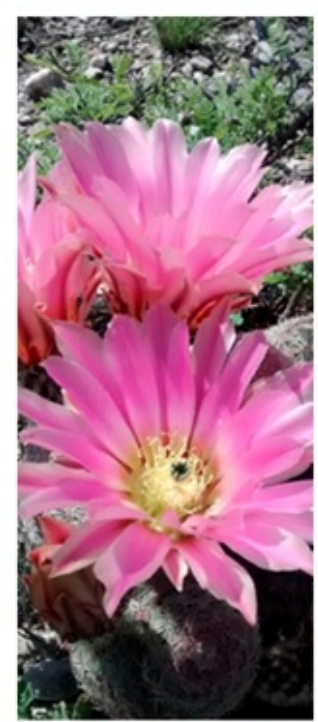

Echinocereus pectinatus

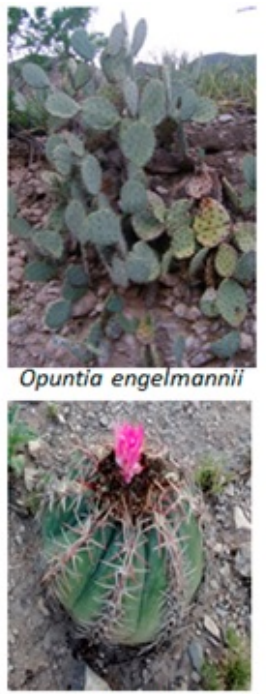

Echinocactus

horizonthalonius

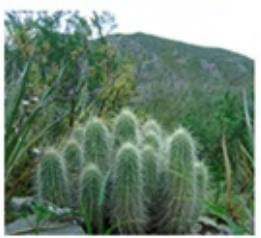

Echinocereus coccineus

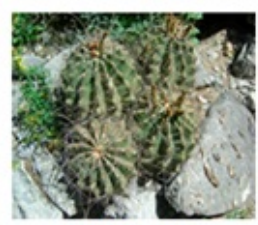

Ferocactus

hamatacanthus

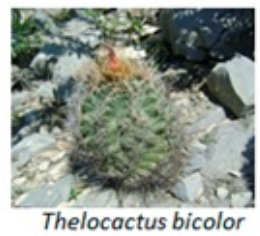

Figure 2. Cactus flora of the Sierra del Rosario, Durango, Mexico.

nificant values $(p<0.05)$, indicating that the work represents a small sample of a log-normal community, with weak interactions, independent birth and death rates, and a high immigration rate. Significant values in the log-normal distribution are characteristic of stable communities that grow exponentially and respond independently to factors, with populations in small patches (Moreno and Halffter
2001, Aguirre et al. 2008). This indicates that the Sierra del Rosario is an isolated mountain in the midst of flat areas with xerophilous shrubland, rugged orography and no current signs of severe disturbances, which is why its cactus populations are in a good state of conservation. This offers an advantage for declaring the Sierra del Rosario as a stateadministered Protected Natural Area, which would 

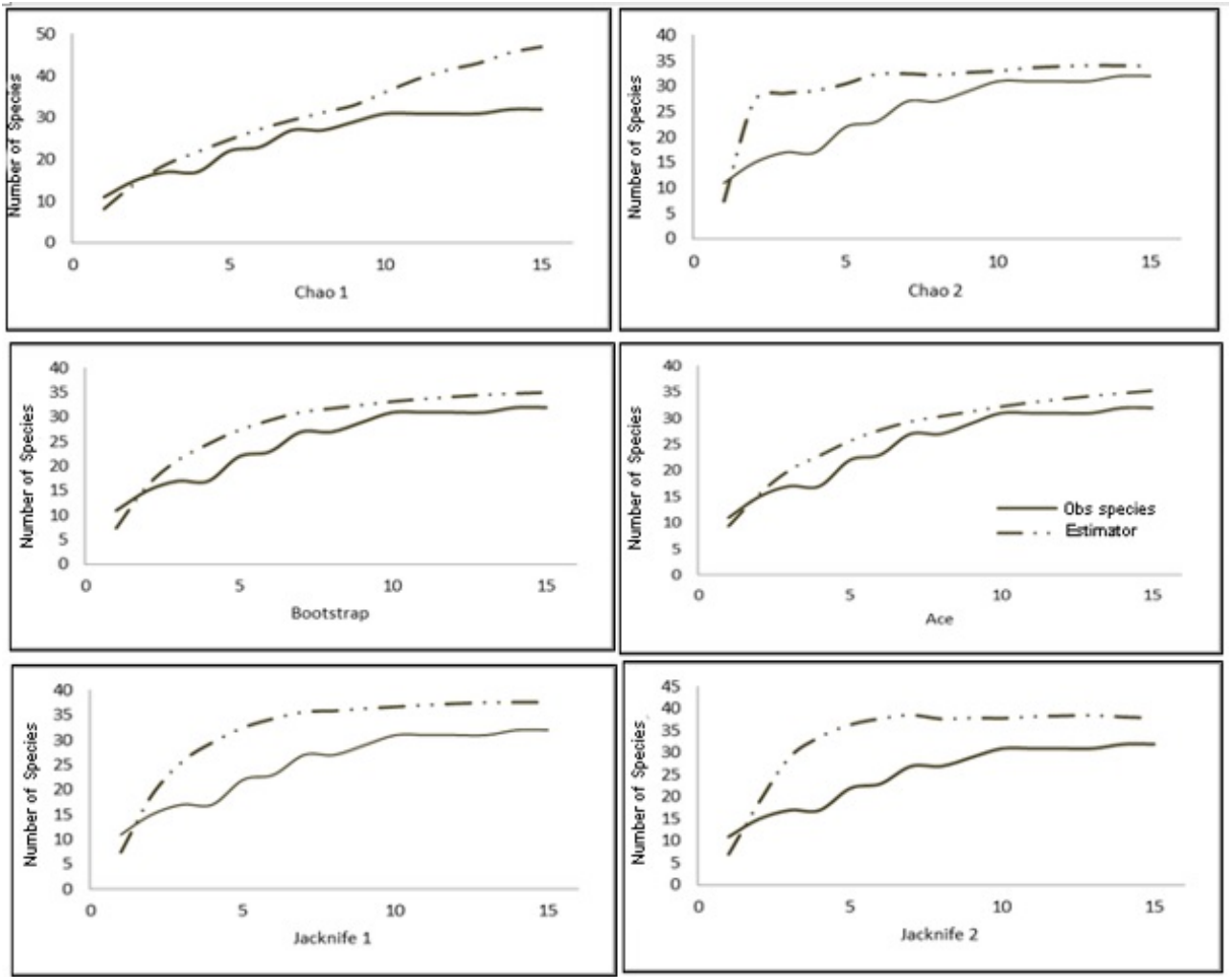

Figure 3. Total number of cactus species and analysis of diversity estimators.

benefit the other endemic species that inhabit it.

Cluster analysis showed four groups that were differentiated by species composition. Each group has different elevational ranges, type of vegetation and exposure (east and west) in the northern and southern portions of the Sierra del Rosario. In general, the greatest diversity and abundance of cacti were found in the elevational range from 1 207 to 1437 masl, with dominant vegetation of microphyllous desert shrubland located in the southern portion of the sierra. The largest group comprised two subgroups that cluster the largest number of samples, with a similarity coefficient of 0.30 , and share the species Coryphantha durangensis, C. tuberculosa, C. echinus, Cylindropuntia imbricata, C. leptocaulis and Echinocereus coccineus. The group comprising transects 12,11 and 9 has an elevation range of 1800 to 2155 masl and shares the species C. durangensis, C. echinus, Echinocactus horizonthalonius, E. pectinatus, E. enneacanthus,
E. dasyacanthus and Corynopuntia schottii; it is characterized by being located in the northern portion of the sierra, with west exposure and scant rainfall, and the predominant vegetation type is rosetophyllous desert shrubland in transition to chaparral, with low winter temperatures and canyon orography. The group corresponding to transects 14 and 6 was isolated at a cut-off level of 0.18 , and only have one species in common (Thelocactus bicolor) with an elevation of 1393 to 1922 masl; it is characterized by having a vegetation type transitional to chaparral, rugged orography and higher humidity conditions. The analysis shows that one of the four groups was isolated at a cut-off level of 0.32 and corresponds to transect 10 that goes from 2,000 to 2,352 masl; it was the most dissimilar, located at the highest elevation, and had as an exclusive species Mammillaria lasiacantha (Figure 4). For similarity indices, studies in Mexico's arid zones indicate that concentrations of cactus species are 


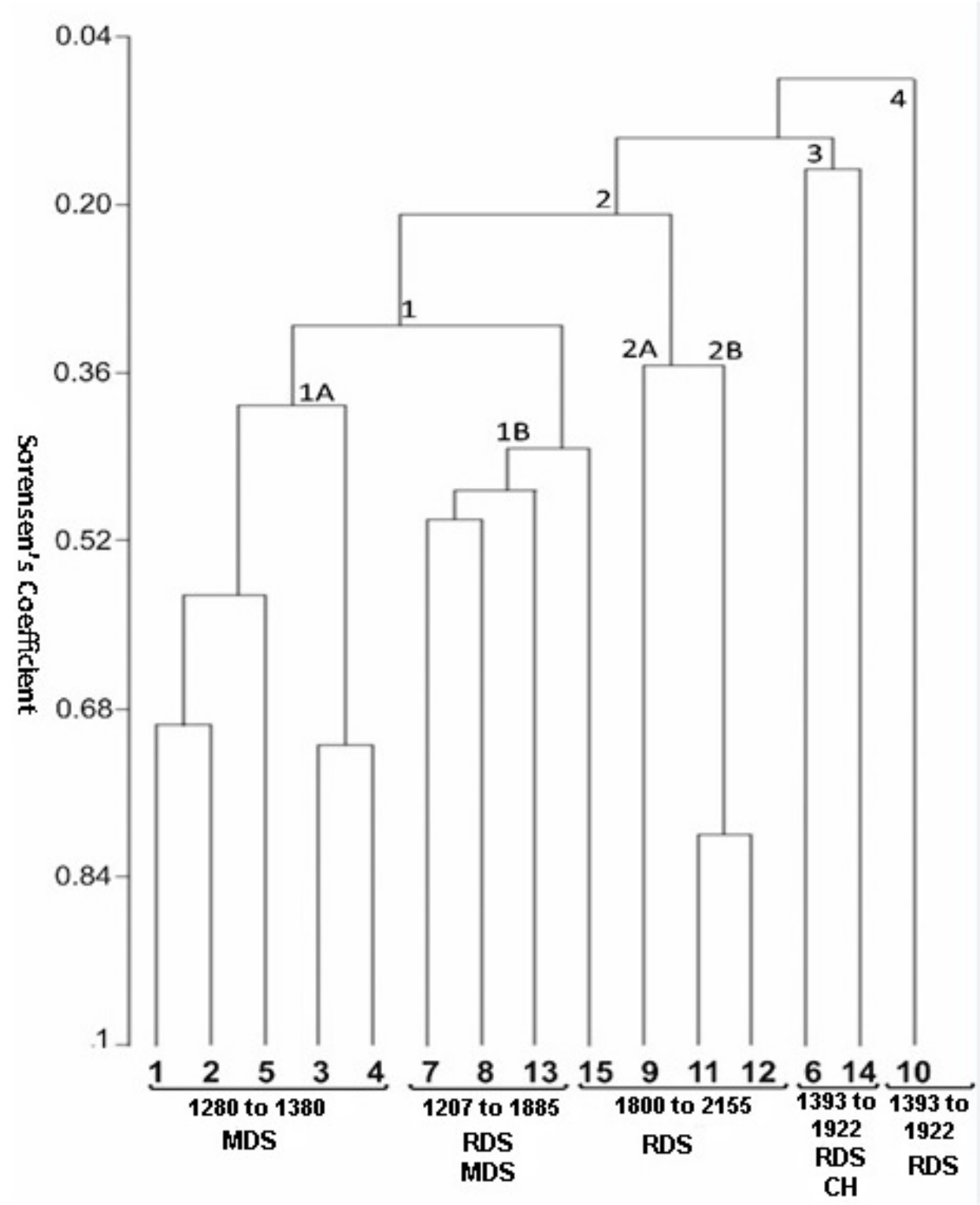

Figure 4. Clustering of sampling transects based on analysis of similarity, relationship to vegetation types and elevational ranges. MDS = microphyllous desert shrubland, RDS = rosetophyllous desert shrubland and $\mathrm{CH}=$ Chaparral. 13931922.

preferentially located in xerophilous, microphyllous and rosetophyllous desert shrubland ecosystems that offer habitats made up of valleys with hills (Hernández et al. 2004, Hernández and Hinostrosa 2011). This coincides with what was reported for the Sierra del Rosario, since the highest species richness was located where microphyllous shrublands with an elevational gradient from 1207 to 1437 masl pre- dominate, because the elevation provides heterogeneity of relief and climates for the distribution of a higher number of cactus species associated with different environmental conditions. In this regard, Sánchez et al. (2014) indicate the importance of the aridity gradient in the distribution of cacti, favoring their presence in arid zones and decreasing it in wet zones, as happens in the Sierra del Rosario, which is 


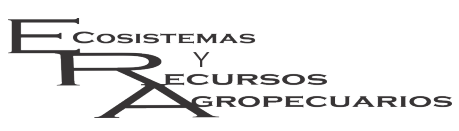

Estrada-Arellano et al. Diversity of Cactaceae in Sierra del Rosario, Mexico

Ecosist. Recur. Agropec. 5(13):133-141,2018

why in shaded ravines with submontane shrubland vegetation or bushy oaks their abundance decreases.

The cactus flora of the Sierra del Rosario accounts for $5 \%$ of Mexico's cactus species. Species richness estimators show the existence of up to 47 species, indicating a high diversity of this taxonomic group in the study area. Abundance models indicate an ecosystem rich in species and with little distur- bance, being both stable and growing. The species have a distribution associated with the elevational gradient, with the low and middle zones being the richest, and diversity decreasing with altitude. The southern zone of the Rosario mountain range has a greater diversity of cacti than the north, owing to the amplitude in the gradient and the heterogeneity of the relief.

\section{LITERATURE CITED}

Aguirre O, Corral J, Vargas B, Jiménez J (2008) Evaluación de modelos de diversidad-abundancia del estrato arbóreo en un bosque de niebla. Revista Fitotecnia Mexicana 31: 281-289.

Bárcenas RT (2006) Comercio de cactáceas mexicanas y perspectivas para su conservación. Biodiversitas 68: $11-15$.

Colwell RK (2013) EstimateS 9.1. 0 User's Guide. Connecticut: University of Connecticut. http://viceroy.eeb. uconn.edu/EstimateS/. Date consulted: February 02, 2016.

Godínez-Alvarez H, Valverde T, Ortega-Baes P (2003) Demographic trends in the cactaceae. Botanical Review 69: 173-203.

Gómez-Díaz JA, Krömer T, Carvajal-Hernéndez Cl, Gerold G, Heitkamp F (2017) Richness and distribution of herbaceous angiosperms along gradients of elevation and forest disturbance in central Veracruz, Mexico. Botanical Science 95: 1-22.

González Elizondo M, Elizondo G, Arrieta SH (1991) Flora de Durango. Listados florísticos de México. Universidad Nacional Autónoma de México, Instituto de Biología. 167p.

Gotelli NJ, Colwell RK (2001) Quantifying biodiversity: procedures and pitfalls in the measurement and comparison of species richness. Ecology Letters 4: 379-391.

Guzmán U, Arias S, Dávila P (2007) Catálogo de autoridades taxonómicas de las cactáceas (Cactaceae: Magnoliopsida) de México. Facultad de Estudios Superiores Iztacala, UNAM. Base de datos SNIBCONABIO, proyectos Q045 y AS021. México. http://www.biodiversidad.gob.mx/especies/gran_familia /plantas/magnoliayMarg/docs/Cactaceas.pdf Date consulted: June 10, 2015.

Hernández HM, Gómez C, Goettsch B (2004) Checklist of Chihuahuan Desert Cactaceae. Harvard Papers in Botany 9: 51-68.

Hernández HM, Gómez-Hinostrosa C (2011) Mapping the Cacti of Mexico. Succulent Plant Research. Vol. 7. DH Books. Milborn Port, RU. 128p.

Hernández JG, Chávez RJ, Sánchez E (2007) Diversidad y estrategias para la conservación de cactáceas en el semidesierto Queretano. Biodiversitas 70: 6-9.

INEGI (2001) Conjunto de datos vectoriales fisiográficos, escala 1:10000000, (continuo nacional). INEGI. Aguascalientes, Ags. México. http://www.inegi.org.mx/geo/contenidos/recnat/fisiografia/ Date consulted June 20, 2015.

INEGI (2011) Conjunto de datos vectoriales de uso de suelo y vegetación, escala 1:250000, serie V (continuo nacional). INEGI. Aguascalientes, Ags. México. http://www.inegi.org.mx/geo/contenidos/recnat/uso suelo/. Date consulted June 20, 2015. 
Lebgue T, Viramontes O, Soto R, Quiñónez M, Balderrama S, Aviña Y (2011) Cactáceas endémicas y raras del estado de Chihuahua, México. Tecnociencia Chihuahua 5: 27-33.

López A, Williams G (2006) Evaluación de métodos no paramétricos para la estimación de la riqueza de plantas leñosas en cafetales. Boletín de la Sociedad Botánica de México 78: 7-15.

Mabberley DJ (1997) The plant-book: a portable dictionary of the vascular plants. Cambridge University Press. UK. 858p.

Magurran A (2004) Measuring Biological Diversity. England Blackwell Pub. Oxford. 260p.

McCune B (1997) Influence of noisy environmental data on canonical correspondence analysis. Ecology 78 : 2617-2623.

Moreno CE, Halffter G (2001) On the measure of sampling effort used in species accumulation curves. Journal of Applied Ecology 38: 487-490.

Ortega-Baes P, Godínez-Alvarez H (2006) Global diversity and conservation priorities in the Cactaceae. Biodiversity and Conservation 15: 817-827.

Rzedowski J (2015) Catálogo preliminar de plantas vasculares de distribución restringida a la Sierra Madre Oriental. Flora del Bajío y de regiones adyacentes. Fascículo complementario XXI. CONABIO-INECOL. Michoacán, México. 39p.

Sánchez J, Estrada E, Muro G, Arias S, García-Aranda M, García L (2014) Diversidad cactoflorística de la zona árida y semiárida de Durango, México. Interciencia 39: 794-802.

Sánchez J, Muro G, Romero U (2004) Sierra el Sarnoso: Cactáceas. UJED-ESB, Durango, México. 133p.

SEMARNAT (2010) Norma Oficial Mexicana NOM-059-SEMARNAT-2010. Protección Ambiental Especies Nativas de México de Flora y Fauna Silvestres-Categorías de Riesgo y Especificaciones para su Inclusión, Exclusión o Cambio-Lista de Especies en Riesgo. Diario Oficial de la Federación. 2a Sección, 30 de diciembre de 2010.

Sosa V, De-Nova JA (2012) Endemic angiosperm lineages in Mexico: hotspots for conservation. Acta Botanica Mexicana 100: 293-315.

Villarreal H, Álvarez M, Córdoba S, Escobar F, Fagua G, Gast F et al. (2004) Manual de métodos para el desarrollo de inventarios de biodiversidad. Programa de inventarios de biodiversidad. Instituto de investigación de recursos biológicos Alexander von Humboldt. Bogotá, Colombia. 236p.

Villaseñor JL (2016) Checklist of the native vascular plants of Mexico. Revista Mexicana de Biodiversidad 87: 559-902. 
